\title{
Parasite communities of Scartichthys viridis (Pisces: Blenniidae) from Central Chile: locality vs. host length
}

\author{
Comunidades de parásitos de Scartichthys viridis (Pisces: Blenniidae) \\ de Chile central: localidad $v$ s. longitud del hospedador \\ Pilar Muñoz-Muga ${ }^{1}$ and Gabriela Muñoz $^{1}$ \\ ${ }^{1}$ Facultad de Ciencias del Mar y de Recursos Naturales, Universidad de Valparaíso, Valparaíso. \\ Casilla 5080, Reñaca, Viña del Mar, Chile \\ pilar.munoz@cienciasdelmar.cl
}

\begin{abstract}
Resumen.- Se describen y comparan las comunidades de parásitos en el pez blénido Scartichthys viridis de El Tabo y Las Cruces, dos localidades cercanas de Chile central. Catorce especies parásitas fueron encontradas, cuatro de ellas fueron persistentes a través de las muestras. Hubo una correlación positiva y significativa entre la riqueza, la abundancia infracomunitaria de parásitos y la longitud total del hospedador. Scartichthys viridis de ambas localidades tuvo similar
\end{abstract}

composición parasitaria, aunque las diferencias locales en los descriptores parasitarios poblacionales y comunitarios, mayores en peces de Las Cruces, podrían atribuirse a que el tamaño corporal del hospedador fue significativamente mayor en Las Cruces que en el Tabo.

Palabras clave: Parásitos metazoos, pez blénido, tamaño corporal del hospedador

\section{Introduction}

The diminishing proportion of shared species between two communities with increasing geographical distance is an obvious feature of natural systems (Hengeveld 1990, Huston 1994, Rosenzweig 1995, Brown \& Lomolino 1998, Hubbell 2001). This relationship observed in parasite communities, in which there is evidence that distance between host populations affects similarity in the species composition of parasite communities (Poulin \& Morand 1999). However, some studies have demonstrated that hosts, of a certain species, collected from close localities may have different parasite communities (e.g. Muñoz et al. 2002). These results indicate that other factors, such as specific environmental conditions of each locality and displacement capacities of hosts and parasites may produce differences in parasite communities in hosts from close localities.

In 2007, during several sampling surveys performed in ponds from two close localities, observations showed apparent differences in the parasite communities of blennies. The blenny Scartichthys viridis (Valenciennes, 1836) (Pisces: Blenniidae) is an abundant species that lives in intertidal ponds along the rocky coast of Central Chile (Varas \& Ojeda 1990, Muñoz \& Ojeda 2000, Ojeda et al. 2000). This fish recruits into intertidal ponds when reaches $30 \mathrm{~mm}$ of total length, whereas adults can measure up to $310 \mathrm{~mm}$ (Muñoz \& Ojeda 2000). There are two previous studies on parasites of this fish species, one considered temporal variation of parasite communities in a locality of central Chile (Díaz \& George-Nascimento 2002) and the other compared the parasites between host species of Scartichthys and localities of northern Chile (Flores \& George-Nascimento 2009).

Scartichthys viridis has 30-40\% of site fidelity, which means that this fish returns constantly to the same ponds (pers. comm. Dr. Ojeda ${ }^{1}$ ). This life feature can affect the relationship with other species, such as competitors, prey and parasites, in different localities because the flora and fauna of each place are usually not the same. Therefore, it is possible to expect that specimens of $S$. viridis may harbor different composition and load of parasites even though they come from close localities. In this context, this research describes and compares the parasite communities of $S$. viridis using samples from two close localities from Central Chile.

\section{Material and methods}

Fish samples were collected from intertidal ponds found

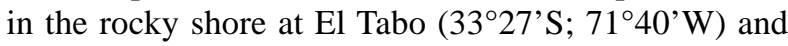

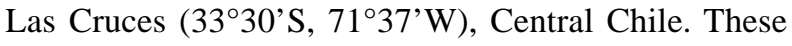

${ }^{1}$ Dr. F. Patricio Ojeda, CASEB, Pontificia Universidad Católica de Chile. 
two localities are about $4 \mathrm{~km}$ apart from each other. The study was done comparing three samples from similar times periods in each locality, to check if the differences of the parasite communities between localities were persistent among the samples. These samples were taken in different austral winter months, July 2007 (sample 1), August 2007 (sample 2) and July 2008 (sample 3), from El Tabo and Las Cruces. The sample sizes were variable among months and localities (Table 1); the total sample size corresponded to 131 specimens from El Tabo and 87 from Las Cruces.
Endo and ectoparasites were collected from each fish according to classical dissection techniques (Díaz \& George-Nascimento 2002). At a parasite population level, prevalence and average abundance were calculated for each parasite species, locality and sample (Bush et al. 1997). At a parasite infracommunity level, average of total abundance and species richness were obtained for sample and locality (Bush et al. 1997). The total prevalence of parasites was also calculated (Díaz \& George-Nascimento 2002). The community descriptors were compared between localities by the means of

Table 1

Parasites found in $S$. viridis. Prevalence $(\mathrm{P}, \%)$ and average abundance $(\mathrm{A}) \pm$ standard deviation for each parasite species, sample and locality

Parásitos encontrados en S. viridis. Prevalencia (P, \%) y abundancia media (A) \pm desviación estándar para cada especie parásita, muestra y localidad

\begin{tabular}{|c|c|c|c|c|c|c|c|}
\hline \multirow[b]{2}{*}{ Parasites } & & \multicolumn{3}{|c|}{ EL TABO } & \multicolumn{3}{|c|}{ LAS CRUCES } \\
\hline & & $\begin{array}{l}\text { Sample } 1 \\
(\mathrm{n}=30)\end{array}$ & $\begin{array}{l}\text { Sample } 2 \\
(n=56)\end{array}$ & $\begin{array}{c}\text { Sample } 3 \\
(n=45)\end{array}$ & $\begin{array}{l}\text { Sample } 1 \\
(\mathrm{n}=20)\end{array}$ & $\begin{array}{c}\text { Sample } 2 \\
(n=16)\end{array}$ & $\begin{array}{c}\text { Sample } 3 \\
(n=51)\end{array}$ \\
\hline \multicolumn{8}{|l|}{ ECTOPARASITES } \\
\hline Piscicolidae gen sp. (Pisc) $\uparrow$ & $\begin{array}{l}\mathrm{P} \\
\mathrm{A}\end{array}$ & $\begin{array}{c}16.7 \\
0.30 \pm 0.84\end{array}$ & $\begin{array}{c}47.4 \\
0.61 \pm 0.97\end{array}$ & $\begin{array}{c}44.4 \\
0.60 \pm 0.78\end{array}$ & $\begin{array}{c}40.0 \\
0.65 \pm 0.99\end{array}$ & $\begin{array}{c}87.5 \\
3.94 \pm 3.91\end{array}$ & $\begin{array}{c}49.0 \\
1.12 \pm 1.84\end{array}$ \\
\hline Acanthochondria sicyasis & $\begin{array}{l}\mathrm{P} \\
\mathrm{A}\end{array}$ & & & & $\begin{array}{c}5.0 \\
0.05 \pm 0.22\end{array}$ & & \\
\hline Lepeophtheirus zbigniewi (Lzib) & $\begin{array}{l}\mathrm{P} \\
\mathrm{A}\end{array}$ & $\begin{array}{c}6.7 \\
0.10 \pm 0.40\end{array}$ & & & $\begin{array}{c}30.0 \\
0.65 \pm 1.27\end{array}$ & $\begin{array}{c}18.7 \\
0.38 \pm 0.89\end{array}$ & $\begin{array}{c}1.9 \\
0.02 \pm 0.14\end{array}$ \\
\hline Colobomatus sp. (Colo) $\dagger$ & $\begin{array}{l}\mathrm{P} \\
\mathrm{A}\end{array}$ & $\begin{array}{c}46.7 \\
0.73 \pm 0.87\end{array}$ & $\begin{array}{c}51.4 \\
0.68 \pm 0.92\end{array}$ & $\begin{array}{c}75.6 \\
1.04 \pm 0.74\end{array}$ & $\begin{array}{c}55.0 \\
1.10 \pm 1.12\end{array}$ & $\begin{array}{c}93.7 \\
2.06 \pm 1.06\end{array}$ & $\begin{array}{c}74.5 \\
1.25 \pm 0.93\end{array}$ \\
\hline Holobomolochus chilensis (Hchi) & $\begin{array}{l}\mathrm{P} \\
\mathrm{A}\end{array}$ & & $\begin{array}{c}2.7 \\
0.04 \pm 0.27\end{array}$ & & & $\begin{array}{c}6.2 \\
0.13 \pm 0.50\end{array}$ & \\
\hline Microcotyle sp. (Micr) & $\begin{array}{l}\mathrm{P} \\
\mathrm{A}\end{array}$ & $\begin{array}{c}13.3 \\
0.33 \pm 1.30\end{array}$ & $\begin{array}{c}31.4 \\
0.48 \pm 0.97\end{array}$ & $\begin{array}{c}6.7 \\
0.24 \pm 1.23\end{array}$ & $\begin{array}{c}35.0 \\
0.95 \pm 1.99\end{array}$ & $\begin{array}{c}56.2 \\
2.00 \pm 3.72\end{array}$ & $\begin{array}{c}51.0 \\
1.25 \pm 1.25\end{array}$ \\
\hline Neobenedenia mellen (Nmel) & $\begin{array}{l}\mathrm{P} \\
\mathrm{A}\end{array}$ & & & $\begin{array}{c}2.2 \\
0.02 \pm 0.15\end{array}$ & $\begin{array}{c}10.0 \\
0.10 \pm 0.31\end{array}$ & & \\
\hline Gyrodactylus sp. $\dagger$ & $\mathrm{P}$ & $\mathrm{nm}$ & $\mathrm{nm}$ & 100.0 & $\mathrm{~nm}$ & $\mathrm{~nm}$ & 96.1 \\
\hline ENDOPARASITES & & & & & & & \\
\hline Lecithasteridae gen sp. (Leci) $\uparrow$ & $\begin{array}{l}\mathrm{P} \\
\mathrm{A}\end{array}$ & $\begin{array}{c}20.0 \\
0.23 \pm 0.50\end{array}$ & $\begin{array}{c}25.7 \\
0.71 \pm 2.35\end{array}$ & $\begin{array}{c}46.7 \\
1.07 \pm 1.83\end{array}$ & $\begin{array}{c}30.0 \\
1.05 \pm 2.11\end{array}$ & $\begin{array}{c}56.2 \\
1.81 \pm 2.26\end{array}$ & $\begin{array}{c}35.3 \\
0.59 \pm 1.13\end{array}$ \\
\hline Helicometrina nimia & $\begin{array}{l}\mathrm{P} \\
\mathrm{A}\end{array}$ & & $\begin{array}{c}1.43 \\
0.02 \pm 0.13\end{array}$ & & & & \\
\hline Monascus filiformis & $\begin{array}{l}\mathrm{P} \\
\mathrm{A}\end{array}$ & & & & $\begin{array}{c}5.0 \\
0.05 \pm 0.22\end{array}$ & & \\
\hline Hemipera sp. & $\begin{array}{l}\mathrm{P} \\
\mathrm{A}\end{array}$ & $\begin{array}{c}3.3 \\
0.03 \pm 0.18\end{array}$ & $\begin{array}{c}1.4 \\
0.05 \pm 0.36\end{array}$ & & & & $\begin{array}{c}2.0 \\
0.02 \pm 0.14\end{array}$ \\
\hline Megasolena sp. (Mega) $\dagger$ & $\begin{array}{l}\mathrm{P} \\
\mathrm{A}\end{array}$ & & $\begin{array}{c}12.9 \\
0.04 \pm 0.19\end{array}$ & $\begin{array}{c}2.2 \\
0.02 \pm 0.00\end{array}$ & $\begin{array}{c}25.0 \\
1.00 \pm 2.92\end{array}$ & $\begin{array}{c}50.0 \\
1.25 \pm 1.88\end{array}$ & $\begin{array}{c}17.6 \\
0.29 \pm 0.73\end{array}$ \\
\hline Corynosoma sp. & $\begin{array}{l}\mathrm{P} \\
\mathrm{A}\end{array}$ & & $\begin{array}{c}1.4 \\
0.02 \pm 0.13\end{array}$ & & & & \\
\hline Average total abundance & & $1.73 \pm 2.58$ & $2.66 \pm 3.80$ & $3.02 \pm 2.61$ & $5.65 \pm 7.70$ & $11.57 \pm 6.38$ & $4.56 \pm 4.17$ \\
\hline Average species richness & & $1.07 \pm 1.28$ & $1.32 \pm 1.15$ & $1.80 \pm 1.10$ & $2.40 \pm 2.26$ & $3.69 \pm 0.95$ & $2.33 \pm 1.26$ \\
\hline
\end{tabular}

$\mathrm{nm}$ : not measured; $\uparrow$ Undescribed species 
ANOVA and contingency tables (Zar 1999). Data on species richness and abundance of parasite infracommunities were log-transformed $(x+1)$ to apply linear regressions with host body length (Zar 1999). ANCOVA was used to compare the slopes of those relationships between localities. A correspondence and a multivariate discriminant analysis was performed between localities to assess differences in composition parasite infracommunities, based in the infracommunity abundance, and a correspondence analysis was applied for prevalence and mean abundance of the parasite species with at least $5 \%$ of prevalence, to associate parasite species and localities (Clarke \& Warwick 1994).

\section{Results}

The total length of Scartichthys viridis had significant differences between localities (ANOVA: $\mathrm{F}_{(1,211)}=80.69$; $P<0.001$ ) and samples (ANOVA: $\mathrm{F}_{(2.211)} \stackrel{11.28 ; P<}{=}$ $0.001)$. The total average length of fish collected from El Tabo $(\overline{\mathrm{X}}=8.00 \pm 2.43 \mathrm{~cm})$ was significantly smaller than Las Cruces $(\bar{X}=11.00 \pm 4.45 \mathrm{~cm})$.

Fourteen parasite taxa were found; eight were ectoparasites and six endoparasites (Table 1). The total prevalence was 74\% in El Tabo and 89\% in Las Cruces, this parasite descriptor was significantly different between localities $\left(\chi^{2}=5.92 ; P=0.015\right)$.

Prevalence and abundance of all parasite species varied between localities and samples (Table 1), although these descriptors tended to be higher in Las Cruces than El Tabo. Four parasite species were the commonest throughout localities and samples (Table 1): Colobomatus sp. (Copepoda), an undetermined leech (Piscicolidae), Microcotyle sp. (Monogenea) and an undetermined species of Lecitastheridae (Digenea). Colobomatus sp. and the leech showed significant differences in abundance between localities ( $P=0.001$ for both species), particularly because the sample 2 from Las Cruces had the highest abundance of these parasites; Microcotyle sp. had higher abundance in Las Cruces than El Tabo in all samples $(P=0.029)$; whereas the abundance of Lecitastheridae gen sp. showed no differences between samples and localities ( $P=0.067)$. The prevalence of these four parasite species was consistently higher in Las Cruces than in El Tabo, when comparing between localities ( $P<0.01$ for all species), however, there were some variations among samples; sample 3 from El Tabo had higher prevalence of Lecitastheridae gen. sp. than Las Cruces, and sample 3 from both localities had similar prevalence of the leech.

The infracommunity abundance was higher in Las Cruces ( $\mathrm{n}=87, \overline{\mathrm{X}}=6.10 \pm 6.11$ parasite individuals) than in El Tabo $(n=131, \bar{X}=2.57 \pm 3.18$ parasite individuals). Similarly, infracommunity species richness of parasites in Las Cruces ( $\overline{\mathrm{X}}=2.57 \pm 1.57$ species) was higher than in El Tabo ( $\overline{\mathrm{X}}=1.44 \pm 1.19$ species $)$.

The abundance of the four commonest parasites significantly correlated to the fish total length $\left(r_{s}>0.32\right.$, $P<0.05$ for these species). The parasite species richness and infracommunity abundance related significantly with host total length in both localities, El Tabo and Las Cruces (Fig. 1). There were significant differences in the slopes of the species richness $(P=0.002)$ and the abundance $(P$ $=0.016)$ related to host body length between localities, although there were no differences in the adjusted means of species richness $(P=0.26)$ and abundances of parasites $(P=0.27)$ between localities.
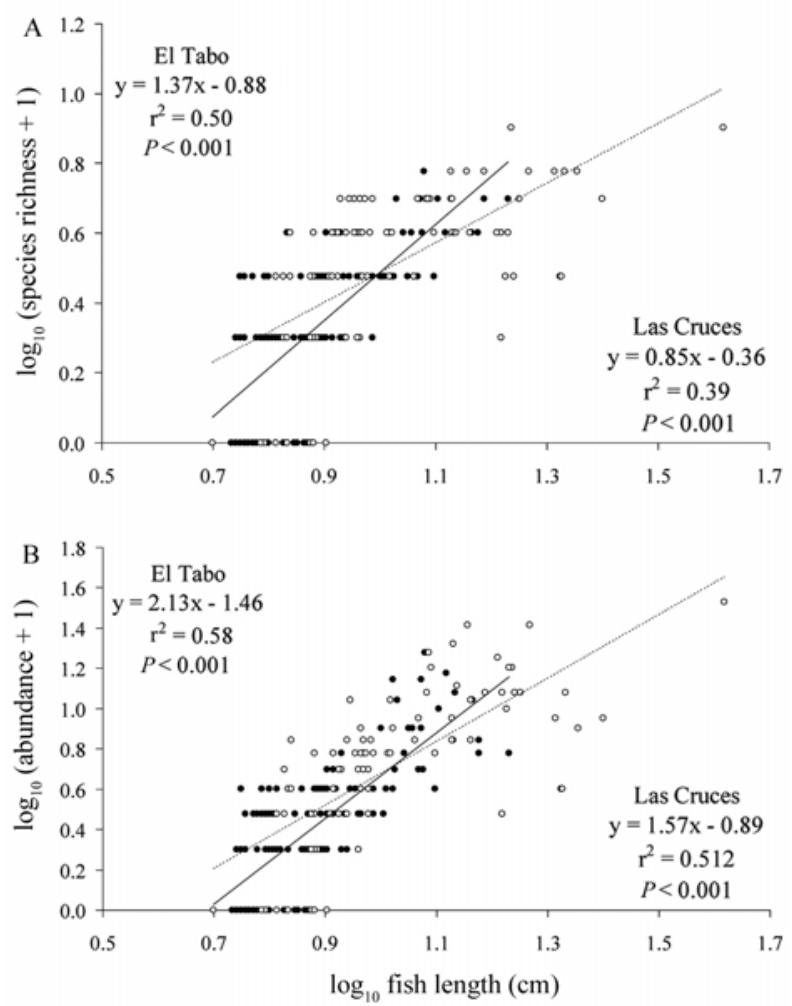

Figure 1

Relationship between A) species richness, B) abundance of parasites and fish total length $(\mathrm{cm})$ of $S$. viridis sampled from El Tabo (black circles-complete line) and Las Cruces (white circles-pointed line)

Relación entre A) riqueza de especies parásitas, B) abundancia y la longitud corporal del hospedador $(\mathrm{cm}) \mathrm{S}$. viridis recolectados de El Tabo (círculos negros-línea completa) y Las Cruces (círculos blancos-línea de puntos) 

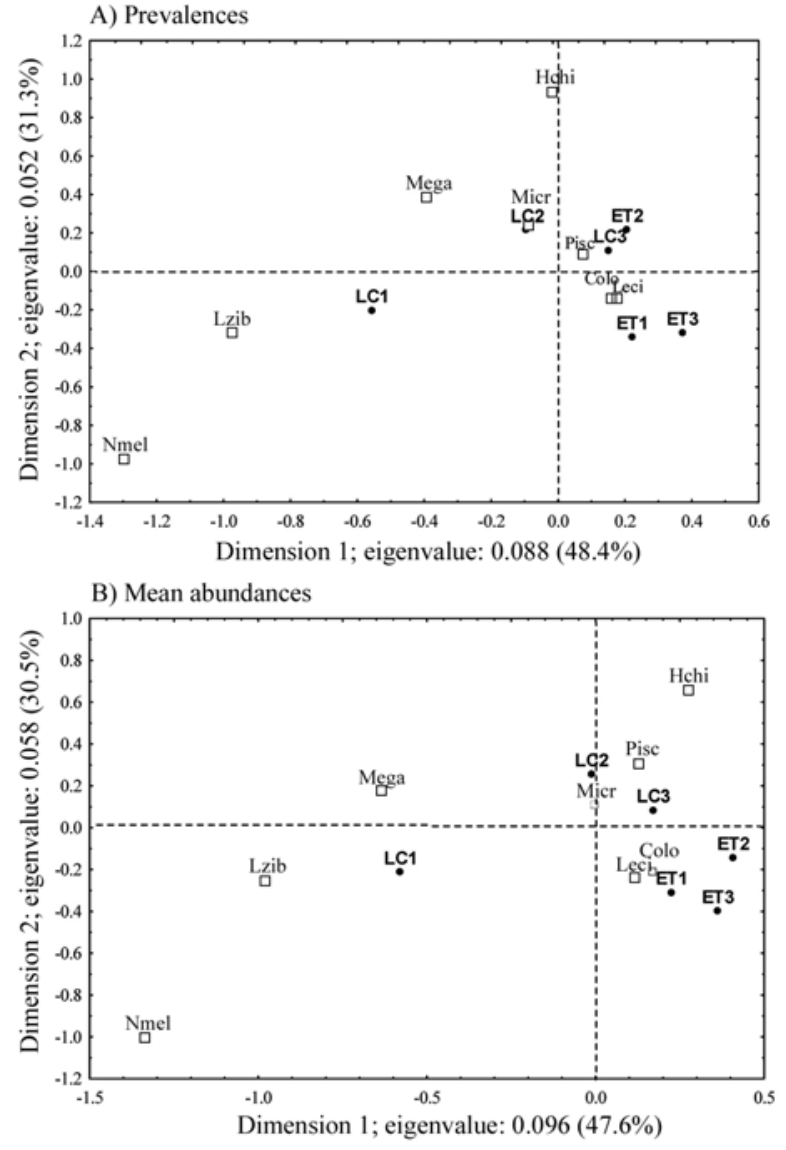

Figure 2

\section{Correspondence analysis between parasite species ( $\square$ ) of Scartichthys viridis and samples (1, 2 and 3$)$ from different localities (•), ET: EI Tabo, LC: Las \\ Cruces, considering A) Prevalence and B) Mean abundance of parasites. Species abbreviation indicated in Table 1}

Análisis de correspondencia entre las especies de parásitos

() de Scartichthys viridis y las muestras (1, 2 y 3) obtenidas de distintas localidades $(\bullet)$, ET: El Tabo,

LC: Las Cruces, considerando A) Prevalencia y

B) Abundancia media de parasitos.

Abreviaciones de las especies indicadas en la Tabla 1

The correspondence analyses, applied for prevalence and mean abundance of parasites, were represented by two dimensional axes that had the highest percentage of variation (Fig. 2a, b). Samples obtained in the same locality were closer than samples from different localities (ET and LC, Fig. 2a, b), especially when parasite mean abundances were considered (Fig. 2b). Some parasite species were associated to different localities, $L$. zbigniewi, Microcotyle sp., Piscicolidae gen sp. Colobomatus sp., and Lecithasteridae gen. sp. and they also differed in prevalence (Fig. 2a) mean abundance (Fig. 2b). One sample from Las Cruces (LC1) was characterized by L. zbigniewi and differed from all the other samples (Table 1, Fig. 2a,b). The discriminant analysis showed that the fish length, and some parasite species (Piscicolidae gen. sp., Microcotyle sp., and Lecithasteridae gen. sp.) had a strong influence in the differences between localities (with F-remove ${ }_{(1,209)}>4.05$ and $P<0.045$ ), in particular the fish length (F-remove ${ }_{(1,}$ 209) $=11.77$ and $P<0.001)$.

\section{Discussion}

This research has shown that Scartichthys viridis harbours a rich parasite community composed of 14 parasite species, which contrasts to the 8 metazoan parasites species found in the same fish species on a previous study from Central Chile (Díaz \& George-Nascimento 2002), although the component community richness and composition of parasite communities were similar to those from Northern Chile (Flores \& George-Nascimento 2009). The present study reports for the first time in $S$. viridis four parasite species, two ectoparasites, Colobomatus sp., Gyrodactylus sp., that had not been reported before in the parasito-fauna of fish from Chile (Muñoz \& Olmos 2007), and two digenean species, Helicometrina nimia, and Hemipera sp., whereas Megasolena sp. was called as Lepidauchen sp. in the other two previous studies (Díaz \& George-Nascimento 2002, Flores \& George-Nascimento 2009). Colobomatus sp. was not found in other studies probably due to its particular position, in the opercular channel, and Gyrodactylus sp. is a small parasite $(0.15 \mathrm{~mm}$ long) that was not easy to observe, in fact, this species was detected during an advanced stage of this research, so only prevalence for the last sample of each locality was calculated.

Parasite communities of Scartichthys viridis from El Tabo and Las Cruces displayed similar specific composition, since the parasites present in only one locality were infrequent. However, fish from Las Cruces had more parasites, showing higher values in prevalence, species richness and abundance, than those from El Tabo. These results remained consistent among samples collected from both localities (Table 1, Fig. 2), meaning that the reported differences of parasite community descriptors occur at different times throughout the year.

The fish total length was a strong predictor for the parasite load, not only for parasite populations but also for parasite communities. The more abundant parasites, such as Piscicolidae gen. sp., Colobomatus sp. Microcotyle sp., and Lecithasteridae gen. sp., were correlated to the fish total length. In addition, the richness 
and abundance of parasite infracommunities increased with the fish total length (Díaz \& George-Nascimento 2002, Flores \& George-Nascimento 2009, the present study). Despite this fact, we found significant differences in the slopes of the relationships of parasitological descriptors and the fish total length, which may be associated to different population dynamics of the parasites according to specific environmental conditions of each locality. There were also significant differences in the average of species richness and abundance of parasites between localities, even though the adjusted means of these two descriptors (according to a common average fish length) were similar between localities. Therefore, the differences found in infracommunity species richness and abundance of parasites might be due to differences in the fish total length, which was also corroborated by the discriminant analysis. Specimens of S. viridis from Las Cruces exhibited higher values of parasite descriptors than the fish from El Tabo, which could be accounted for the larger fish total length registered in the first locality. We do not know what caused the differences in total length of the fish coming from either localities, but the size of the rocky pools might be a factor. The sampled pools from Las Cruces were larger than those from El Tabo, so they might retain larger fish during the tidal ebbing.

Finally, we concluded that the composition of parasite communities of Scartichthys viridis is similar between close localities or localities apart from each other, considering the results by Flores \& George-Nascimento (2009); however, in this research the numerical descriptors of populations and communities of parasites were different between localities just because the fish total length was different. Possibly, larger fish has more parasites than small ones because they are older and have been in contact with parasites for longer. On the other hand, the diet of this fish species changes through ontogeny and the invertebrates, which may transmit parasites, increase in the fish diet as the fish total length increases (Muñoz \& Ojeda 2000).

\section{Acknowledgments}

We thank Dr. Tom Cribb and Dr. Rodney Bray for digenean identification. This research was funded by FONDECYT grant $\mathrm{N}^{\circ} 11060006$. We appreciate the suggestions of two anonymous reviewers, who helped us to improve this manuscript.

\section{Literature cited}

Brown JH \& MV Lomolino. 1998. Biogeography, 691 pp.
Sinauer Press, Sunderland.

Bush AO, KD Lafferty, JM Lotz \& AW Shostak. 1997. Parasitology meets ecology on its own terms: Margolis et al. re-visited. Journal of Parasitology 83: 575-583.

Clarke KR \& RM Warwick. 1994. Change in marine communities: An approach to statistical analysis and interpretation, 144 pp. Natural Environment Research Council, Bournemouth.

Díaz F \& M George-Nascimento. 2002. Estabilidad temporal de las infracomunidades de parásitos en la borrachilla Scartichthys viridis (Valenciennes, 1836) (Pisces: Blenniidae) en la costa central de Chile. Revista Chilena de Historia Natural 75: 641-649.

Flores $\mathbf{K}$ \& $M$ George-Nascimento. 2009. Las infracomunidades de parásitos de dos especies de Scartichthys (Pisces: Blenniidae) en localidades cercanas del norte de Chile. Revista Chilena de Historia Natural 82(1): 63-71.

Hengeveld R. 1990. Dynamic biogeography, 264 pp. Cambridge University Press, Cambridge.

Hubbell SP. 2001. The unified neutral theory of biodiversity and biogeography, 375 pp. Princeton University Press, Princeton.

Huston MA. 1994. Biological diversity: the coexistence of species on changing landscapes, 681 pp. Cambridge University Press, Cambridge.

Muñoz AA \& FP Ojeda. 2000. Ontogenetic changes in the diet of the herbivorous Scartichthys viridis in a rocky intertidal zone in central Chile. Journal of Fish Biology 56: 986-998.

Muñoz G \& V Olmos. 2007. Revisión de especies ectoparásitas y hospedadoras de sistemas acuáticos de Chile. Revista de Biología Marina y Oceanografía 42: 89-148.

Muñoz G, V Valdebenito \& M George-Nascimento. 2002. La dieta y la fauna de parásitos metazoos del torito Bovichthys chilensis Regan 1914 (Pisces: Bovichthyidae) en la costa de Chile centro-sur: variaciones geográficas y ontogenéticas. Revista Chilena de Historia Natural 75: 661671.

Ojeda FP, FA Labra \& AA Muñoz. 2000. Biogeographic patterns of Chilean littoral fishes. Revista Chilena de Historia Natural 73: 625-641.

Poulin R \& S Morand. 1999. Geographical distances and the similarity among parasite communities of conspecific host populations. Parasitology 119: 369-374.

Rosenzweig ML. 1995. Species diversity in space and time, 436 pp. Cambridge University Press, Cambridge.

Varas E \& F Ojeda. 1990. Intertidal fish assemblages of the central Chilean coast: diversity, abundance and trophic patterns. Revista de Biología Marina 25(2): 59-70.

Zar JH. 1999. Biostatistical analysis, 931 pp. Prentice-Hall, Englewood Cliffs. 